\title{
ANALISIS KEBIJAKAN PEYEDIAAN LAHAN HUTAN TANAMAN INDUSTRI \\ (Policy Analysis on Providing Land for Industrial Forest Plantation)
}

\author{
Epi Syahadat \& Sylviani \\ Pusat Penelitian dan Pengembangan Perubahan Iklim dan Kebijakan; Jl. Gunung Batu No. 5, Bogor, \\ Indonesia; e-mail: syahadatepi@yahoo.com; sylvireg@yahoo.co.id
}

Diterima 17 Mei 2014 direvisi 17 September 2014 disetujui 5 November 2014

\begin{abstract}
Policy analysis on providing land for industrial forest plantation is a review of the rules in the provision of land for industrial forest plantation development, legal basis, as well as efforts made by the government to provide land to the legality IUPHHK permit holders to manage a production forest area. In general the purpose of this study is to review the policy of plantation land supply, and in particular to examine: 1) the policy of forest land allocation and distribution; 2) the provision of licensing procedures and requirements of forest crops; 3) implementation gap in forest plantation area supply regulations. The study results showed that there are no policy gap in providing area for industrial forest plantation. The local government follows the mechanism specified by the forestry regulation stated in P.19/2007 Jo P.11/2008 (HTI). IUPHHK permitting process through the mechanism of an application to the Forestry Minister has not been effective and efficient due to: 1) the absence of standard provisions regarding the cost of the permit application process; 2) there is no synchronize between $P .63 / 2008$ with article 5 (letters $f$ and $g$ ) in $P .11 / 2008$ regarding the request of recommendation to the governor.
\end{abstract}

Keywords: Policy, land, industrial forest plantations.

\begin{abstract}
ABSTRAK
Analisis kebijakan penyediaan lahan HTI adalah suatu kajian terhadap aturan main dalam penyediaan lahan untuk pembangunan hutan tanaman, dasar hukum, serta upaya yang dilakukan oleh pemerintah untuk memberikan aspek legalitas lahan kepada pemegang ijin IUPHHK-HT untuk mengelola suatu kawasan hutan produksi. Tujuan penelitian ini adalah mengkaji kebijakan penyediaan lahan hutan tanaman dan secara khusus mengkaji: 1) kebijakan alokasi dan distribusi lahan hutan tanaman; 2) tatacara dan persyaratan perijinan penyediaan lahan hutan tanaman dan 3) gap implementasi peraturan penyediaan lahan hutan tanaman. Hutan tanaman yang dikaji adalah: hutan tanaman industri (HTI). Hasil kajian menunjukan bahwa tidak ada gap kebijakan dalam penyediaan lahan hutan tanaman. Pemerintah daerah mengikuti mekanisme yang sudah ditentukan oleh Kementerian Kehutanan yang tertera dalam P.19/2007 Jo P.11/2008 (untuk HTI). Proses perijinan IUPHHK melalui mekanisme permohonan kepada Menteri Kehutanan belum efektif dan efisien disebabkan oleh: 1) belum adanya ketentuan yang baku mengenai besarnya biaya dalam proses permohonan ijin dan 2) adanya ketidak singkronan bunyi pasal dalam P.63/2008 dengan bunyi pasal 5 (huruf $f$ dan g) dalam P.11/2008 mengenai permohonan rekomendasi Gubernur.
\end{abstract}

Kata kunci: Kebijakan, lahan, hutan tanaman industri. 


\section{PENDAHULUAN}

Kawasan hutan dituntut untuk dapat memberikan manfaat bagi kesejahteraan masyarakat yang sekaligus dapat melakukan perannya sebagai penyangga kehidupan. Seperti telah dipahami bahwa masih banyak masyarakat yang berada di sekitar hutan bergantung kepada keberadaan hutan sebagai sumber mata pencaharian untuk menopang kehidupannya. Ini semua merupakan sebagian permasalahan, dan sekaligus merupakan tantangan yang harus dihadapi oleh sektor kehutanan. Sehubungan dengan hal tersebut maka diterbitkan Permenhut No. P.19/2007 Jo P.11/2008 sebagai tindak lanjut dari PP No. 6/2007 Jo PP No. 3/2008. Sampai dengan bulan Juni 2009 terdapat permohonan Izin Usaha Pemanfaatan Hasil Hutan Kayu (IUPHHK) Hutan Tanaman sebanyak 262 pemohon (Dirjen BPK, 2009). Konsekuensinya pemerintah dalam hal ini adalah Kementerian Kehutanan harus mencadangkan kawasan hutan yang ada untuk dijadikan lahan/areal pembangunan hutan tanaman. Untuk menghindari terjadinya konflik (sosial dan ekonomi) dengan masyarakat berkaitan de-ngan pembangunan hutan tanaman tersebut, ada beberapa hal yang penting dan strategis untuk diperhatikan, di antaranya adalah: 1) dasar hukum dan kepastian hukum terkait dengan lahan hutan tanaman (kebijakan penyediaan lahan hutan tanaman); 2) mekanisme perijinan IUPHHK dan 3) implementasi dari aturan tersebut. Pencadangan areal hutan tanaman tersebut memerlukan tapak, di mana seringkali tapak tersebut belum teridentifikasi dengan jelas, baik luasan, lokasi maupun sistem pendistribusiannya.

Analisis kebijakan penyediaan lahan hutan tanaman adalah suatu kajian terhadap aturan main atau dasar hukum dalam penyediaan lahan untuk pembangunan hutan tanaman, sekaligus merupakan upaya yang dilakukan oleh pemerintah untuk memberikan aspek legalitas lahan kepada pemegang ijin IUPHHK hutan tanaman dalam mengelola suatu kawasan hutan produksi. Kajian tersebut dilakukan dengan mengkaji aturan main atau dasar hukum dalam penyediaan lahan untuk pembangunan hutan tanaman. Kajian ini difokuskan pada: 1) perspektif dasar hukum dan analisis prosedur kebijakan atau aturan yang terkait dengan penyediaan lahan hutan tanaman dan 2) implementasi kebijakan penyediaan lahan hutan tanaman yang meliputi evaluasi implementasi dan perundangan yang terkait dengan penyediaan lahan hutan tanaman.

Sumber daya hutan memiliki peran sebagai penghasil barang dan jasa, penopang sistem kehidupan sosial ekonomi dan budaya masyarakat serta sistem penyangga kehidupan. Kondisi ini mengakibatkan kawasan hutan cenderung dialihfungsikan untuk penggunaan di luar sektor kehutanan. Permasalahan lain yang dihadapi adalah terjadinya konflik (sosial dan ekonomi) dengan masyarakat berkaitan dengan pembangunan hutan tanaman, di mana sebagian kawasan hutan yang dicadangkan untuk dijadikan lahan/areal pembangunan hutan tanaman secara de facto telah digunakan untuk kegiatan di luar sektor kehutanan, hal ini sangat berpengaruh terhadap daya saing investasi. Untuk meningkatkan tingkat kepercayaan publik (public trust) dan adanya kepastian hukum atau adanya legalitas lahan hutan tanaman, maka perlu perhatian dan penanganan yang serius dari pemerintah. Tujuan kajian ini adalah: 1) mengkaji kebijakan penetapan lokasi pencadangan lahan hutan tanaman dan 2) mengkaji prosedur atau tatacara dan persyaratan perijinan penyediaan lahan hutan tanaman serta gap peraturan tersebut di dalam pelaksanaannya. Sasaran dari kajian ini adalah: 1) identifikasi kelemahan dan kelebihan kebijakan penetapan lokasi pencadangan lahan hutan tanaman; 2) identifikasi 
kelemahan dan kelebihan kebijakan distribusi pengelolaan hutan tanaman dan 3) identifikasi kelemahan dan kelebihan prosedur/tatacara dan persyaratan perijinan penyediaan lahan hutan tanaman serta gap di dalam pelaksanaannya. Ruang lingkup kajian ini dibatasi pada Ijin IUPHHK di hutan tanaman industri, dengan mengacu UU No. 41 tahun 1999 tentang Kehutanan, PP No. 6/2007 Jo PP No. 3/2008 dan Permenhut No. P.19/2007 Jo P.11/2008. Pembahasan dalam kajian ini menggunakan terminologi IUPHHK pada hutan tanaman Industri (HTI).

\section{METODE PENELITIAN}

\section{A. Kerangka Pemikiran}

Analisis Kebijakan Penyediaan Lahan Hutan Tanaman adalah suatu kajian yang meliputi aspek luasan dari lahan hutan tanaman yang dicadangkan, lokasi hutan tanaman, distribusi pengelolaan dan prosedur atau aturan main penyediaan lahan hutan tanaman untuk memberikan aspek legalitas lahan kepada pemegang ijin IUPHHK untuk mengelola suatu kawasan hutan produksi pada suatu periode tertentu. Menurut pasal 51 ayat (1) PP No. 6/2007 jangka waktu pemberian ijin untuk IUPHHK HTI dalam hutan tanaman selama 100 tahun (pasal 53 ayat 1). Penelitian ini menggunakan pola pikir yang berorientasi terhadap aspek-aspek utama dan pendukung yang menyebabkan keberhasilan maupun kegagalan dari pelaksanaan pembangunan hutan tanaman sebagaimana Gambar 1.

Dalam rangka revitalisasi sektor kehutanan, upaya yang dapat dilakukan antara lain melalui pengembangan investasi baru oleh pelaku usaha dan mencegah hilangnya potensi pendapatan negara serta mencegah maraknya perambahan hutan. Untuk menjamin keberhasilan program tersebut, kepastian hukum berkaitan lahan hutan tanaman, kebijakan atau aturan main dalam mekanisme perijinan IUPHHK hutan tanaman industi merupakan suatu hal yang penting dan strategis untuk diperhatikan.

\section{B. Pengumpulan Data}

Data yang dikumpulkan adalah data primer dan data sekunder. Data sekunder antara lain meliputi Peraturan Perundangan mengenai pemanfaatan dan pengelolaan kawasan hutan, baik yang dikeluarkan oleh Kementerian Kehutanan atau kementerian teknis lainnya, Undang-Undang yang dikeluarkan oleh Pemerintah Republik Indonesia, dan laporan yang terkait dengan pembangunan HTI yang dikeluarkan oleh NGO atau instansi penelitian lainnya. Data primer diperoleh dari hasil wawancara dengan berbagai pihak terkait di setiap tingkat wilayah. Responden dalam penelitian ini adalah: 1) Ditjen Bina Produksi Kehutanan; 2) Ditjen Planologi; 3) Pusat Informasi Kehutanan; 4) Unit Pelaksana Teknis Dirjen Bina Produksi Kehutanan; 5) Dinas Kehutanan Provinsi; 6) Dinas Kehutanan Kabupaten; 7) Pemerintah Daerah; 8) Pemilik Perusahaan IUPHHK hutan tanaman dan 9) Tokoh masyarakat sekitar hutan. Dari hasil wawancara dengan responden tersebut diharapkan akan ditemukan pendapat dan hasil yang beragam mengenai kebijakan penyediaan lahan hutan tanaman. 
Tujuan

Identifikasi

masalah

Proses

Analisis

Sintesa
Analisis kebijakan penyediaan lahan Hutan Tanaman Industri

Tata kelola industri dan perdagangan hasil hutan khususnya dalam penyediaan lahan hutan tanaman belum berjalan sebagaimana mestinya

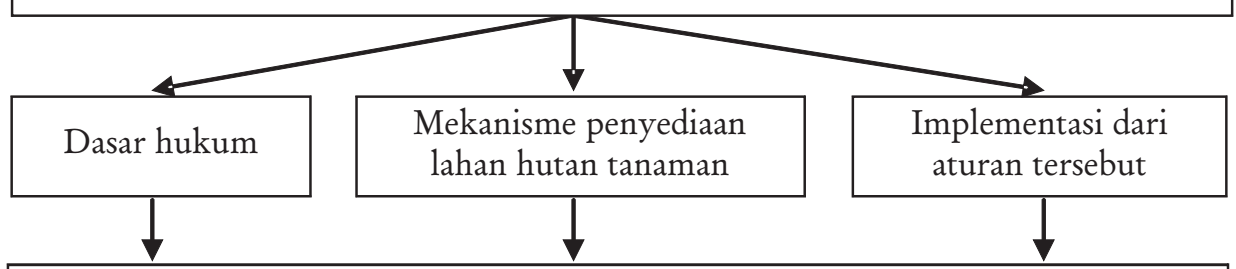

FaktorFaktor utama dan pendukung yang berpengaruh terhadap pelaksanaan pembangunan hutan tanaman dikaitkan dengan aturan yang berlaku,

karakteristik sumberdaya, peran stakebolders/aktor dalam penyediaan lahan hutan tanman

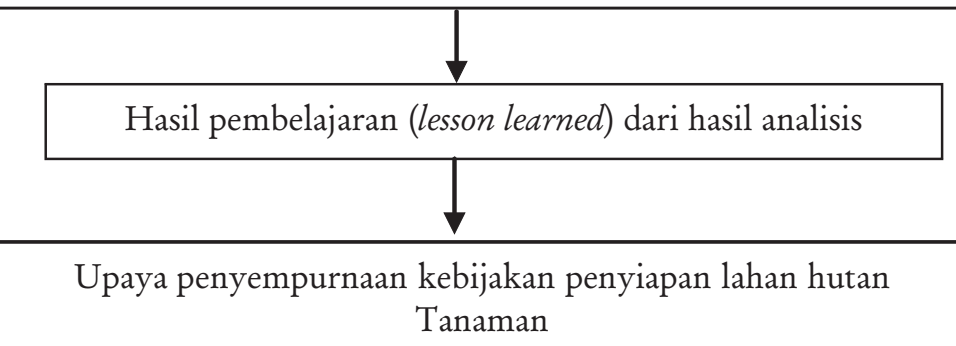

Gambar 1. Alur pikir metodologi penelitian analisis kebijakan penyediaan lahan hutan tanaman industri. Figure 1. Methodology framework policy analysis on providing land for industrial forest plantation.

Penentuan sampel dilakukan secara purposive sampling, yaitu penentuan sampel dengan pertimbangan tertentu (Sugiyono, 2004). Sampel yang diambil adalah stakebolder yang terkait dengan pemberian ijin dan pelaksanaan IUPHHK hutan tanaman industri. Metode pengambilan secara purposive ini dilakukan karena tidak semua orang/ pihak mengetahui, memahami, terlibat dan terkena dampak dari kegiatan pemberian ijin dan pelaksanaan IUPHHK hutan tanaman.

\section{Metode Analisis}

Penelitian ini menggunakan pendekatan analisis deskriptif-kuantitatif dengan melakukan kajian faktor-faktor yang menyebabkan adanya keinginan setiap daerah untuk mengembangkan hutan tanaman dengan mengubah status kawasan hutan di Indonesia. Faktor-faktor tersebut meliputi: 1) Faktor sosial, yaitu masalah konflik lahan seperti tumpang-tindih status lahan, perubahan status pembangunan kawasan, penyerobotan lahan masyarakat; 2) Faktor ekonomi, yaitu pembiayaan dan rentabilitas usaha hutan tanaman relatif rendah atau kurang memberikan keuntungan. Hasil pengumpulan data kemudian diolah dan ditabulasikan: 1) Biaya pengurusan IUPHHK (biaya transaksi); 2) Lamanya proses pengurusan IUPHHK; 3) Informasi keberadaan standar operasional prosedur (SOP) dan 4) Proses pengurusan ijin satu pintu (one stop service) yang dapat dilihat pada Lampiran 1, 2, 3 dan 4.

Analisis yang digunakan untuk mengetahui struktur kebijakan dan regulasi penyediaan lahan hutan tanaman disesuaikan dengan tujuan yang akan dicapai yaitu:

1. Untuk mengetahui prosedur/tatacara dan persyaratan perijinan lahan hutan tanaman dilakukan melalui analisis prosedur. 
Analisis tersebut dilakukan karena tahapan proses perijinan IUPHHK dianggap dapat membuka peluang terjadinya penyimpangan, indikasi tersebut di analisis dari empat kriteria, yaitu: Transparansi (T), Partisipasi (P), Akuntabilitas (A) dan Efektivitas (E). Keempat kriteria tersebut diadopsi dari berbagai kriteria dan indikator good governance yang dikemukakan oleh UNDP, ADB, MTI dan Partnership For Governance (PGR) yang terkait dengan kelemahan dalam mekanisme sistem permohonan ijin IUPHHK kepada Menteri Kehutanan pada hutan tanaman yang tertera dalam Permenhut No. P.11/2008.

2. Untuk mengetahui gap antara peraturan perundangan dalam implementasinya, digunakan gap analysis. Tujuan analisis ini adalah untuk mengidentifikasi gap antara peraturan dan implementasi serta membantu organisasi/lembaga dalam mengungkapkan bagian yang harus diperbaiki. Gap analysis dapat menjadi dasar untuk mengukur investasi waktu, uang dan tenaga kerja yang dipakai.

3. Untuk mengetahui biaya transaksi yang dikeluarkan dalam proses perijinan IUPHHK hutan tanaman, dilakukan wawancara dengan cara memberikan pertanyaan terkait biaya transaksi yang dikeluarkan oleh pemohon ijin tersebut, antara lain:

a. Biaya informasi yang terdiri dari biaya mengurus surat perijinan, biaya meman- tau dalam mengurus perijinan IUPHHK ke instansi terkait dan biaya pendirian badan usaha.

b. Biaya koordinasi yang terdiri dari biaya pengawasan dan biaya transportasi dalam proses permohonan ijin IUPHHK.

c. Biaya strategis yang terdiri dari biaya jamuan dalam proses permohonan ijin IUPHHK kepada instansi terkait.

\section{HASIL DAN PEMBAHASAN}

\section{A. Hasil}

\section{Gambaran Umum}

Jumlah IUPHHK-HTI sampai dengan Juni 2009 sebanyak 262 unit (seluas 11.457.241 ha), dengan rincian sebagaimana tertera pada Tabel 1.

Sejak diterbitkannya Permenhut No. P.19/2007 Jo. P.11/2008 sebagai tindak lanjut dari PP No. 6/2007 Jo. PP 3/2008 sampai dengan bulan Juni 2009 terdapat permohonan IUPHHK-HT sebanyak 262 pemohon dan realisasi penanaman areal HTI seluas $25.180 \mathrm{ha}$. Jumlah investasi kumulatif dari 36 IUPHHKHT yang melaporkan s/d bulan Juni 2009 sebesar Rp 12.732.388.610.140,- (Ditjen BPK, 2009) dengan penyerapan tenaga kerja sebanyak 12.591 orang.

Tabel 1. Perkembangan HTI sampai dengan Juni 2009.

Tabel 1. Progress of forest plantation up to June 2009.

\begin{tabular}{clcc}
\hline No & Uraian (Description) & Jumlah (Total) (Unit) & Luas (Areas) (ha) \\
\hline 1 & SK IUPHHK-HT Definitif & 172 & 7.602 .421 \\
2 & SK IUPHHK-HT Pencadangan & 58 & 3.221 .145 \\
3 & SK Sementara IUPHHK-HT & 32 & 633.675 \\
\hline
\end{tabular}

Sumber (Source): Direktorat Jenderal Bina Produksi Kehutanan (2009). 
Sejak diterbitkannya Permenhut No. P.19/2007 Jo. P.11/2008 sebagai tindak lanjut dari PP No. 6/2007 Jo. PP 3/2008 sampai dengan bulan Juni 2009 terdapat permohonan IUPHHK-HT sebanyak 262 pemohon dan realisasi penanaman areal HTI seluas $25.180 \mathrm{ha}$. Jumlah investasi kumulatif dari 36 IUPHHKHT yang melaporkan s/d bulan Juni 2009 sebesar Rp 12.732.388.610.140,- (Ditjen BPK, 2009) dengan penyerapan tenaga kerja sebanyak 12.591 orang.

\section{Perspektif Dasar Hukum Pembangunan Hutan Tanaman Indonesia (HTI)}

Dasar hukum yang digunakan dalam pemberian ijin IUPHHK hutan tanaman melalui mekanisme permohonan kepada Menteri Kehutanan, adalah sebagai berikut:

a. Undang-Undang No. 41 tahun 1999 tentang Kehutanan.

b. Peraturan Pemerintah No. 6 tahun 2007 tentang Tata Hutan dan Penyusunan Rencana Pengelolaan Hutan serta Pemanfaatan Hutan.

c. Peraturan Menteri Kehutanan No. P.11/ 2008 tentang Perubahan Kedua Permenhut No. P.19/2007 tentang Tata Cara Pemberian Izin dan Perluasan Areal Kerja Usaha Pemanfaatan Hasil Hutan Kayu pada Hutan Tanaman Industri dalam Hutan Tanaman pada Hutan Produksi.

d. Keputusan Menteri Kehutanan No. 177/ 2003 tentang Kriteria dan Indikator Pengelolaan Hutan secara Lestari pada Unit Manajemen Usaha Pemanfaatan Hutan Tanaman.

e. Peraturan Menteri Kehutanan No. P.60/ 2007 tentang Perubahan Peraturan Menteri Kehutanan No. P.19/2007 tentang Tata Cara Pemberian Izin dan Perluasan Areal Kerja Usaha Pemanfaatan Hasil Hutan Kayu pada Hutan Tanaman Industri dalam
Hutan Tanaman pada Hutan Produksi.

\section{Mekanisme Permohonan IUPHHK-HT}

Sistem perijinan pemanfaatan kayu merupakan suatu sistem yang mengatur persyaratan yang harus dipenuhi untuk memperoleh ijin pengelolaan dan pemanfaatan hutan, pihak yang dapat diberikan ijin, tata cara pemberian ijin dan kewenangan pemberian ijin. Dalam proses pemberian IUPHHK dimaksudkan untuk memberikan kesempatan seluas-luasnya kepada masyarakat yang ingin memanfaatkan hutan melalui IUPHHK. Hal tersebut dilakukan untuk mendapatkan penawar yang profesional dan berkualitas serta mempunyai komitmen tinggi dalam pemanfaatan hutan secara lestari, bahkan peroranganpun dapat mendaftarkan diri sebagai calon pemohon IUPHHK hutan tanaman. Dalam pelaksanaannya, proses tersebut tidak menarik para investor karena proses yang terlalu birokratis dan berbiaya tinggi sehingga banyak investor yang mundur. Hal ini diindikasikan dari jumlah ijin IUPHHK yang tidak bertambah secara siginifikan dalam kurun waktu dua tahun.

Dalam PP No. 6 tahun 2007 pasal 62 ayat (1) dan ayat (3) dinyatakan bahwa IUPHHK hutan tanaman diberikan berdasarkan rekomendasi Gubernur yang telah mendapatkan pertimbangan dari Bupati/Walikota (Gambar 2). Dalam pasal 68 ayat (1) dinyatakan bahwa IUPHHK pada hutan tanaman diberikan dengan cara mengajukan permohonan.

Dalam PP 6/2007 dinyatakan bahwa pemberian ijin IUPHHK pada hutan tanaman dilakukan dengan menyeleksi para pemohon ijin dan status kawasan hutan yang dimohon (pasal 68, ayat 2). Ketentuan lebih lanjut mengenai tata cara pemohon ijin IUPHHK diatur dengan Peraturan Menteri (pasal 68, 


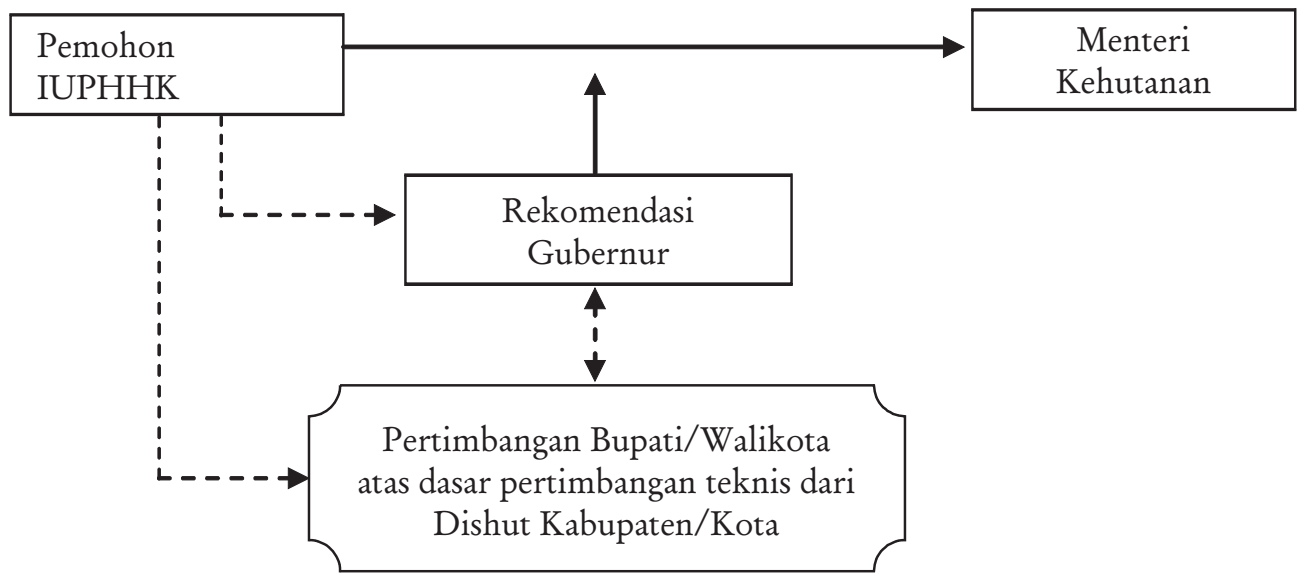

Gambar 2. Mekanisme permohonan ijin IUPHHK berdasarkan PP No. 6/2007. Figure 2. Application for permit IUPHHK mechanism based on PP No. 6/2007.

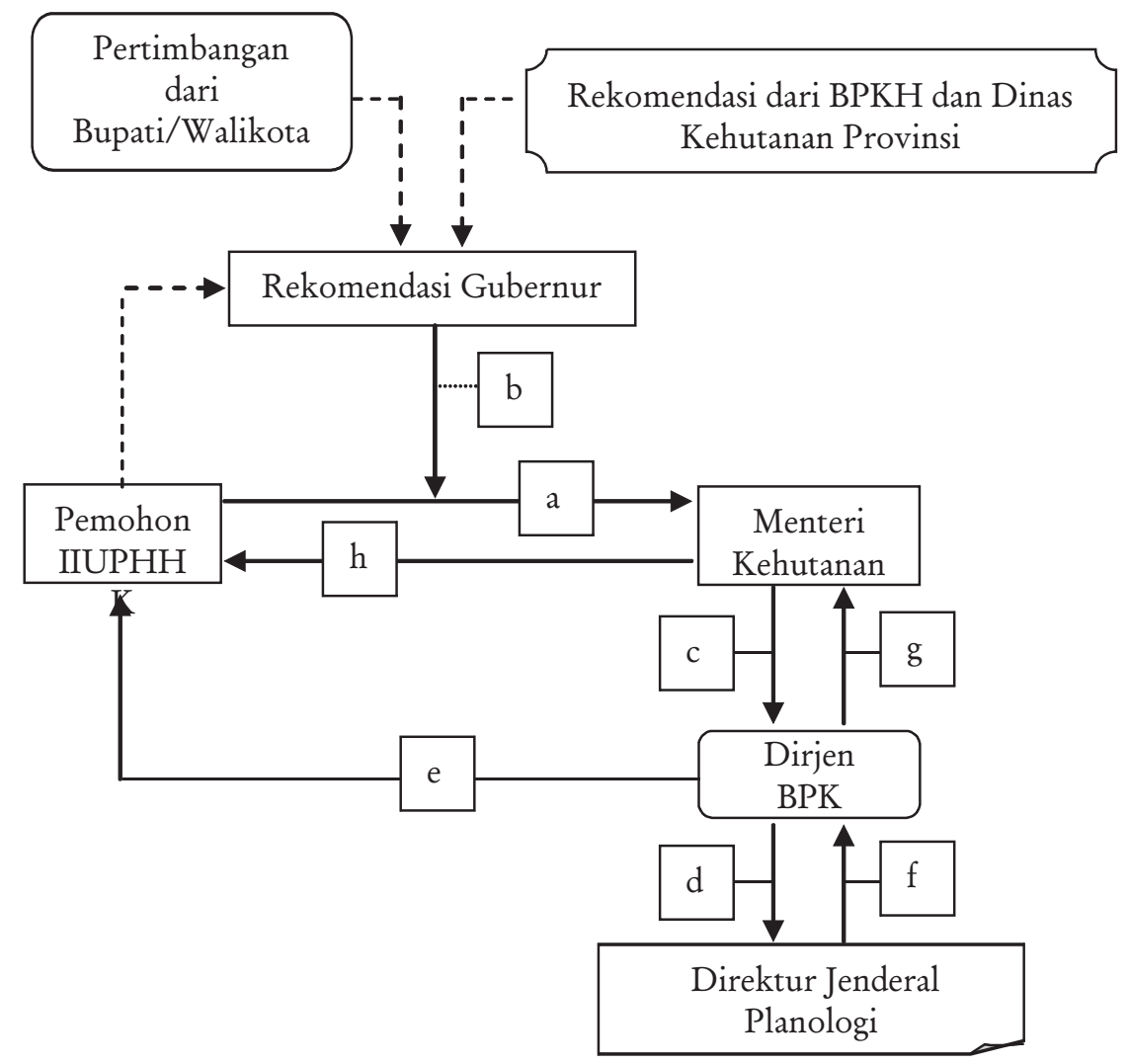

Gambar3. Alur permohonan ijin IUPHHK hutan tanaman berdasarkan Permenhut No. P.11/2008.

Figure 3. License application flow IUPHHK forest plantation based on Permenhut No. P.11/2008. 
Keterangan Gambar 3:

a. Pemohon mengajukan permohonan ijin IUPHHK kepada Menteri Kehutanan.

b. Rekomendasi Gubernur atas dasar pertimbangan dari Bupati/Walikota dan pertimbangan teknis dari BKPH dan Dinas Kehutanan Provinsi.

c. Menteri meminta Direktorat Jenderal BPK untuk memeriksa kelengkapan administrasi.

d. Direktorat Jenderal BPK melakukan pemeriksaan kelengkapan persyaratan administrasi, apabila terpenuhi Dirjen BPK meminta konfirmasi areal lahan kepada Dirjen Planologi.

e. Apabila persyaratan administrasi tidak terpenuhi maka Dirjen BPK dan Menteri Kehutanan menerbitkan surat penolakan.

f. Dirjen Planologi memberikan hasil konfirmasi areal kepada Dirjen BPK berupa peta calon areal kerja.

g. Berdasarkan hasil konfirmasi areal yang diberikan oleh Dirjen Planologi apabila tidak ada masalah (clean and clear), Dirjen BPK melakukan penilaian proposal teknis dan hasilnya disampaikan kepada Menteri Kehutanan.

h. Atas dasar hasil penilaian proposal teknis dan konfirmasi areal yang diberikan oleh Dirjen BPK, Menteri Kehutanan menerima atau menolak permohonan ijin IUPHHK tersebut.

Dari Gambar 2 dan Gambar 3 dapat dilihat terdapat delapan perspektif yang perlu diperhatikan dalam proses pemberian ijin IUPHHK hutan tanaman melalui mekanisme permohonan kepada Menteri Kehutanan, yaitu:

a. Untuk memperoleh ijin IUPHHK para pemohon harus melalui proses yang cukup panjang dan kompleks. Sebelum menetapkan pelaksanaan pemberian ijin IUPHHK melalui mekanisme permohonan kepada Menteri Kehutanan, Dirjen BPK dan
Menteri Kehutanan terlebih dahulu menyeleksi para pemohon dan memastikan status kawasan hutan yang akan diberikan kepada para pemohon. Untuk pemohon ijin IUPHHK hutan tanaman, Dirjen BPK melakukan pemeriksaan atas kelengkapan persyaratan administrasi dalam waktu 10 hari (P. 11/2008 pasal 7 , ayat 1 ).

b. Setiap pemohon IUPHHK pada hutan tanaman mengajukan surat permohonan kepada Menteri Kehutanan dengan menyertakan proposal teknis dan persyaratan administrasi, termasuk rekomendasi Gubernur dan Bupati/Walikota. Pada poin ini dapat dikatakan bahwa pemerintah daerah juga dilibatkan dalam proses permohonan IUPHHK untuk areal IUPHHK yang berada di wilyahnya.

c. Dari tahap pertama yaitu seleksi terhadap para pemohon IUPHHK yang dilakukan oleh Ditjen BPK, apabila berkas permohonan tersebut telah memenuhi persyaratan yang diminta dan lolos seleksi, akan dilanjutkan ke tahap berikutnya. Apabila berkas permohonan yang diajukan kepada Menteri Kehutanan tidak memenuhi persyaratan yang telah ditentukan, maka dalam waktu tujuh hari kerja sejak penilaian, berkas permohonan tersebut dikembalikan kepada pemohon. Hal ini menunjukkan adanya upaya mewujudkan transparansi kepada para pemohon yang lain untuk dapat mengikuti proses selanjutnya dalam mekanisme permohonan IUPHHK kepada Menteri Kehutanan.

d. Dalam hal permohonan memenuhi kelengkapan persyaratan, selambat-lambatnya tujuh hari kerja, Menteri Kehutanan menerbitkan surat perintah kepada pemohon untuk menyusun dan menyampaikan AMDAL, Upaya Kelola Lingkungan (UKL), dan Upaya Pemantauan Lingkungan (UPL) sesuai peraturan undang-undang yang berlaku. 
e. Perorangan, koperasi BUMS, BUMD maupun BUMN dapat menjadi peserta dan mendaftarkan diri sebagai calon pemohon ijin IUPHHK kepada Menteri Kehutanan. Setiap calon pemohon berhak mendapatkan penjelasan mengenai proses permohonan tersebut. Penjelasan tersebut meliputi metode seleksi pemohon, dokumen yang harus disampaikan, metode evaluasi dokumen yang harus dilampirkan dalam permohonan areal hutan yang akan diberikan sesuai dengan dokumen pencadangan kawasan hutan.

f. Dalam hal kewajiban pemohon IUPHHK hutan tanaman untuk menyusun AMDAL tidak terpenuhi dalam jangka waktu paling lama 150 hari, atau tidak memenuhi UKL dan UPL dalam jangka waktu 60 hari, surat persetujuan permohonan ijin dari Menteri Kehutanan dibatalkan (Permenhut No. P.19/2007 pasal 10 ayat 1$)$.

g. Berdasarkan laporan AMDAL atau UKL dan UPL, Menteri Kehutanan menginstruksikan Dirjen Planologi Kehutanan untuk menyiapkan peta areal kerja (working area $=W A$ ) IUPHHK-HTI paling lambat 15 hari kerja dan menyampaikannya kepada Direktur Jenderal BPK; berdasarkan peta areal kerja IUPHHK-HTI
Direktur Jenderal BPK menyiapkan konsep keputusan tentang pemberian IUPHHKHTI kepada Menteri Kehutanan melalui Sekretaris Jenderal Departemen Kehutanan (Permenhut No. P.11/2008 pasal 11, ayat 1 dan ayat 2).

h. Dalam waktu enam hari kerja setelah pemohon menerima SK pemegang ijin IUPHHK-HT, Direktur Jenderal BPK menerbitkan Surat Perintah Pembayaran Iuran Ijin Usaha Pemanfaatan Hutan (SPPIIUPH). Keputusan tentang pemberian ijin IUPHHK akan dibatalkan apabila pemegang ijin IUPHHK hutan tanaman tidak melunasi IIUPH dalam waktu yang ditentukan sesuai dengan Peraturan Menteri Kehutanan.

\section{Analisis Prosedur Pembangunan Hutan Tanaman Industri (HTI)}

Keseluruhan tahapan dalam proses perijinan IUPHHK melalui mekanisme permohonan kepada Menteri Kehutanan yang ditunjukan pada Gambar 2 dan Gambar 3 dianggap dapat membuka kesempatan terjadinya penyimpangan. Indikasi tersebut dianalisis dari empat kriteria (Tabel 2), yaitu: Tranparansi (T), Partisipasi (P), Akuntabilitas (A) dan Efektivitas (E).

Tabel 2. Tahapan proses perijinan IUPHHK yang berpotensi terjadi penyimpangan. Table 2. Stages of IUPHHK licensing process potential on irregularities.

\begin{tabular}{|c|c|c|c|}
\hline No & $\begin{array}{l}\text { Tahapan kegiatan } \\
\text { (Stages of activity) }\end{array}$ & $\begin{array}{l}\text { Kriteria yang tidak } \\
\text { terpenuhi (Criteria } \\
\text { are not fulfilled) }\end{array}$ & Keterangan (Explanation) \\
\hline 1 & $\begin{array}{l}\text { Persyaratan administrasi } \\
\text { mewajibkan adanya rekomendasi } \\
\text { Gubernur atas pertimbangan dari } \\
\text { Bupati/Walikota }\end{array}$ & $(\mathrm{T})(\mathrm{P})(\mathrm{A})$ & $\begin{array}{l}\text { Rekomendasi dari Gubernur merupakan } \\
\text { perwujudan adanya pembagian } \\
\text { kewenangan antara pusat dan daerah } \\
\text { dalam kerangka otonomi daerah. Untuk } \\
\text { menghindari adanya penyelewengan } \\
\text { harus dibuat suatu dasar acuan dalam } \\
\text { pemberian rekomendasi mengacu kepada } \\
\text { UU No. } 32 \text { tahun } 2004 \text { tentang } \\
\text { Pemerintahan Daerah dan PP } 38 / 2007 \\
\text { tentang Pembagian Urusan Antara } \\
\text { Pemerintah, Pemerintah Daerah Provinsi } \\
\text { dan Pemerintah Daerah Kabupaten/Kota }\end{array}$ \\
\hline
\end{tabular}


Tabel 2. Lanjutan.

Table 2. Continued.

\begin{tabular}{|c|c|c|c|}
\hline No & $\begin{array}{l}\text { Tahapan kegiatan } \\
\text { (Stages of activity) }\end{array}$ & $\begin{array}{l}\text { Kriteria yang tidak } \\
\text { terpenuhi (Criteria } \\
\text { are not fulfilled) }\end{array}$ & Keterangan (Explanation) \\
\hline 2 & $\begin{array}{l}\text { Seleksi terhadap pemohon ijin } \\
\text { IUPHHK }\end{array}$ & $(\mathrm{T})(\mathrm{P})(\mathrm{A})$ & $\begin{array}{l}\text { - Secara umum kriteria seleksi pemohon } \\
\text { yang digunakan bersifat objektif, tetapi } \\
\text { masih terdapat poin-poin tertentu yang } \\
\text { bersifat kualitatif sehingga unsur } \\
\text { subyetivitas penilai cukup dominan } \\
\text { - Hasil seleksi terhadap pemohon ijin } \\
\text { IUPHHK tidak dapat } \\
\text { dipertanggungjawabkan akuntabilitasnya }\end{array}$ \\
\hline 3 & $\begin{array}{l}\text { Uji kelayakan pemohon ijin } \\
\text { IUPHHK }\end{array}$ & $(\mathrm{T})(\mathrm{P})(\mathrm{E})$ & $\begin{array}{l}\text { - Belum ada kriteria yang baku dalam } \\
\text { melaksanakan kegiatan uji kelayakan } \\
\text { pemohon ijin IUPHHK sehingga lebih } \\
\text { mengarah pada subjektivitas } \\
\text { - Tidak ada transparansi dan akuntabilitas } \\
\text { dalam uji kelayakan }\end{array}$ \\
\hline 4 & $\begin{array}{l}\text { Dirjen BPK menyampaikan } \\
\text { berkas pemohon yang telah } \\
\text { memenuhi persyaratan } \\
\text { administrasi kepada Menteri } \\
\text { Kehutanan }\end{array}$ & (T) $(\mathrm{A})$ & $\begin{array}{l}\text { Pemohon yang telah memenuhi } \\
\text { persyaratan administrasi diajukan kepada } \\
\text { Menteri untuk diikutsertakan dalam } \\
\text { tahap berikutnya. Sejauhmana } \\
\text { pemeriksaan administrasi tersebut dapat } \\
\text { dipertanggungjawabkan hasilnya, karena } \\
\text { pemohon ijin IUPHHK mungkin lebih } \\
\text { dari satu, dan untuk hal tersebut belum } \\
\text { ada kriteria yang baku }\end{array}$ \\
\hline 5 & $\begin{array}{l}\text { Dirjen BPK meminta konfirmasi } \\
\text { areal kepada Dirjen Planologi } \\
\text { Kehutanan berupa peta calon } \\
\text { areal kerja. }\end{array}$ & (T) $(\mathrm{A})$ & $\begin{array}{l}\text { Permohonan konfirmasi lahan oleh } \\
\text { Dirjen BPK kepada Dirjen Planologi } \\
\text { Kehutanan terkesan kurang/tidak efektif } \\
\text { dan efisien, mengingat pengajuan } \\
\text { permohonan ijin IUPHHK harus disertai } \\
\text { rekomendasi Gubernur. Rekomendasi } \\
\text { Gubernur akan diberikan apabila sudah } \\
\text { ada hasil telaah kawasan hutan yang } \\
\text { dilakukan oleh BPKH setempat }\end{array}$ \\
\hline 6 & $\begin{array}{l}\text { Penyusunan AMDAL dan UKL } \\
\text { / UPL }\end{array}$ & (A) & $\begin{array}{l}\text { - Tidak efisien, apabila pemohon ijin tidak } \\
\text { menyusun AMDAL dan UPL/UKL, } \\
\text { padahal pemohon ijin IUPHHK telah } \\
\text { menghabiskan banyak biaya dan cukup } \\
\text { menyita waktu dalam proses } \\
\text { permohonan ijinnya. } \\
\text { - Apabila pemohon ijin IUPHHK tidak } \\
\text { menyusun AMDAL dan UPL/UKL } \\
\text { langsung dibatalkan dan dikenakan } \\
\text { sanksi, tidak perlu diberikan surat } \\
\text { peringatan terlebih dahulu karena } \\
\text { penyusunan AMDAL dan UPL/UKL } \\
\text { sudah merupakan persyaratan yang harus } \\
\text { dipenuhi dan telah sesuai dengan aturan } \\
\text { yang berlaku }\end{array}$ \\
\hline
\end{tabular}


Tabel 2. Lanjutan.

Table 2. Continued.

\begin{tabular}{clll}
\hline No & $\begin{array}{c}\text { Tahapan kegiatan } \\
\text { (Stages of activity) }\end{array}$ & $\begin{array}{c}\text { Kriteria yang tidak } \\
\text { terpenuhi (Criteria } \\
\text { are not fulfilled) }\end{array}$ & \multicolumn{1}{c}{ Keterangan (Explanation) } \\
\hline 7 & $\begin{array}{l}\text { Dirjen Planologi Kehutanan } \\
\text { menyiapkan Peta Areal Kerja } \\
\text { dan Bahan Penetapan Tebangan }\end{array}$ & (T) (A) & $\begin{array}{l}\text { Tidak diatur waktu penyiapan Peta Areal } \\
\text { dan Bahan Penetapan Tebangan Tahunan } \\
\text { oleh Dirjen Planologi Kehutanan agar } \\
\text { dapat mengikuti jadwal pemberian } \\
\text { IUPHHK }\end{array}$ \\
\hline 8 & Pembayaran IIUPH & (A) & $\begin{array}{l}\text { Harus dibuat suatu aturan yang baku } \\
\text { mengenai kepastian pemohon yang telah } \\
\text { memperoleh ijin IUPHHK, kewajiban } \\
\text { untuk membayar IIUPH harus dipenuhi, } \\
\text { dan akan dikenakan sanksi apabila tidak } \\
\text { membayar iuran tersebut }\end{array}$ \\
\hline
\end{tabular}

Keempat kriteria tersebut diadopsi dari berbagai kriteria dan indikator good governance yang telah dikemukakan oleh United Nation Developement Program (UNDP), Asian Developement Bank (ADB), Masyarakat Transparansi Indonesia (MTI) dan Partnership for Governance Reform (PGR), terkait dengan kelemahan sistem permohonan IUPHHK pada hutan tanaman dalam Permenhut No. P.19/2007 Jo P.11/2008.

\section{B. Pembahasan}

\section{Kebijakan Penyediaan Lahan Untuk Hutan Tanaman}

Luas kawasan hutan produksi di seluruh Indonesia berdasarkan SK Penunjukan Kawasan Hutan dan TGHK \pm 81.193.178 ha (Ditjen BPK, 2009). Hingga Maret 2009 kawasan hutan produksi (HPT, HP dan HPK) yang telah dimanfaatkan untuk kegiatan usaha pemanfaatan hasil hutan kayu dan peruntukan lainnya seluas $35.856 .072 \mathrm{ha}$. Dengan demikian terdapat sekitar 44.337.106 ha yang belum dibebani ijin usaha pemanfaatan hasil hutan. Secara makro berdasarkan kriteria dan indikator dikelompokkan menjadi unit usulan calon areal usaha yaitu UPHHK-HA, UPHHK-HTI, UPHHK-HTR, UPHHK-HA
Restorasi dan unit usaha lainnya. Kriteria indikator yang digunakan adalah: kondisi penutupan lahan, luas, kelerengan, tipe hutan, potensi (kayu dan non kayu), aksesibilitas, kondisi konflik sosial dan konflik kepentingan.

Berdasarkan kriteria dan indikator dimaksud terhadap kawasan hutan produksi yang tidak dibebani ijin, diusulkan arahan pemanfaatannya menjadi unit calon areal usaha hutan tanaman dengan rincian sebagaimana Tabel 3.

Dari hasil analisis yang dilakukan menunjukkan bahwa penyediaan/pencadangan lahan untuk pembangunan hutan tanaman HTI dan HTR mengikuti mekanisme/aturan yang sudah ditentukan dalam Permenhut No. P.19/2007 Jo P.11/2008 (untuk HTI), P.37/2007 Jo P. 18/2009 (untuk HKm) dan P.23/2007 Jo P.05/2008 (untuk HTR). Hal tersebut dapat dilihat pada Tabel 4 bahwa $100 \%$ respoden menyatakan bahwa tidak ada gap kebijakan dalam penyediaan/pencadangan lahan untuk pembangunan hutan tanaman, karena dalam implementasinya setiap permohonan pembangunan hutan tanaman yang diajukan dari masyarakat/pemohon dengan diketahui oleh pemerintah daerah setempat, dan mekanisme ini sudah tertuang dalam permenhut tersebut di atas. 
Tabel 3. Rician unit calon areal usaha hutan tanaman.

Table 3. The specification of forest plantation potential areal unit.

\begin{tabular}{clcc}
\hline No & $\begin{array}{c}\text { Rencana penggunaan areal usaha (Utilization } \\
\text { area business plan) }\end{array}$ & Luas (Area) (ha) & $\begin{array}{c}\text { Jumlah unit kerja } \\
\text { (Number of units) }\end{array}$ \\
\hline 1 & UPHHK-HA & 13.228 .555 & 90 \\
2 & UPHHK-HT & 10.555 .573 & 141 \\
3 & UPHHK-HTR & 7.167 .278 & 496 \\
4 & UPHHK-Restorasi & 4.418 .442 & 146 \\
5 & Jasa lingkungan & 16.013 & 14 \\
6 & Untuk kawasan lindung & 896.568 & - \\
7 & Untuk HHBK dan HTHR & 2.230 .674 & - \\
8 & Areal non pemanfaatan & 5.824 .003 & - \\
\hline
\end{tabular}

Pembangunan HTI saat ini merupakan salah satu peluang yang masih terbuka untuk penanaman modal di bidang kehutanan mengingat potensi hutan alam sudah menurun dan sudah tidak mampu memenuhi kebutuhan bahan baku kayu bagi industri pengolahan hasil hutan di daerah. Dari data dan informasi yang diperoleh, pelaksanaan pembangunan HTI khususnya dalam proses perijinan IUPHHK dan lain-lain mengikuti aturan yang telah ditentukan oleh Kementerian Kehutanan, di antaranya adalah:

a. Ketentuan Perijinan: Proses perijinan UPHHK-HTI mengikuti prosedur yang tertera dalam Permenhut No. P.19/2007 Jo P.60/2007 Jo P.11/Menhut-II/2008 tanggal 24 April 2008.

b. Standar Biaya Pembangunan: Standar biaya yang digunakan dalam pembangunan HTI mengikuti standar biaya yang dikeluarkan oleh Kementerian Kehutanan sesuai dengan Permenhut No. P.48/Menhut-II/2008 tentang Standar Biaya Pembangunan Hutan Tanaman Industri. Adapun biaya per hektar untuk pembangunan HTI adalah sebesar Rp 9.578.350.

\section{Analisis Prosedur}

Dari hasil analisis prosedur terhadap tahapan kegiatan dalam proses perijinan IUPHHK yang dilakukan, terdapat tiga tahapan yang mempunyai tiga kriteria good governance yang tidak terpenuhi dan dianggap dapat membuka peluang terjadinya penyimpangan, yaitu:

a. Persyaratan administrasi yang mewajibkan adanya rekomendasi Gubernur. Rekomendasi Gubernur merupakan perwujudan adanya pembagian kewenangan antara pusat dan daerah dalam kerangka otonomi daerah. Untuk menghindari adanya penyelewengan harus dibuat suatu dasar acuan dalam pemberian rekomendasi yang mengacu kepada UU No. 32/2004 tentang Pemerintah Daerah dan PP 38/2007 tentang Pembagian Urusan antara Pemerintah, Pemerintah Daerah dan Pemerintah Daerah Kabupaten/ Kota.

b. Seleksi terhadap pemohon ijin IUPHHK. Secara umum kriteria seleksi pemohon yang digunakan bersifat objektif. Akan tetapi dalam pelaksanaannya masih terdapat poinpoin tertentu yang bersifat kualitatif seperti kebanyakan pemohon ijin IUPHHK merupakan salah satu grup industri besar sehingga unsur subjektivitas penilai cukup dominan.

c. Uji kelayakan pemohon ijin IUPHHK. Belum adanya kriteria yang baku dalam melaksanakan kegiatan uji kelayakan pemohon ijin IUPHHK sehingga lebih mengarah pada subyektivitas serta tidak adanya transparansi dan akuntabilitas dalam uji kelayakan. 
3. Gap Kebijakan dalam Penyediaan/ Pencadangan Lahan Hutan Tanaman

Pada Tabel 4 dapat dilihat bahwa 100\% responden menyatakan bahwa dalam proses penyediaan/pencadangan lahan untuk HTI mengikuti mekanisme yang sudah ditentukan oleh Kementerian Kehutanan yang tertuang dalam Permenhut No. P.19/ 2007 Jo P.11/ 2008.

\section{Biaya Transaksi}

Pada Tabel 5 dapat dilihat besarnya biaya yang dikeluarkan dalam pengurusan ijin IUPHHK (biaya transaksi). Sebesar 50\% responden mengatakan bahwa biaya transaksi dalam pengurusan ijin IUPHHK di tingkat pusat berkisar antara Rp 51-100 juta; 33,33\% responden mengatakan bahwa biaya transaksi di tingkat provinsi berkisar antara $\mathrm{Rp}$ 101-150 juta dan $72,22 \%$ responden mengatakan bahwa biaya transaksi dalam pengurusan ijin IUPHHHK di tingkat kabupaten/kota berkisar antara $\mathrm{Rp}$ 51-100 juta. Dari data tersebut rataan biaya transaksi dalam pengurusan ijin IUPHHK dari PusatKabupaten/Kota berkisar antara Rp 67-116 juta.

Dalam peraturan yang ada memang tidak tertera secara eksplisit berapa besarnya biaya pengurusan ijin IUPHHK, tetapi dalam proses perijinan tersebut terdapat klausul yang menyebabkan timbulnya biaya dalam proses pengurusan ijin IUPHHK, contoh bunyi pasal 5 ayat (2 huruf f) Permenhut No. P.11/2008 yang menyatakan bahwa setiap permohonan IUPHHK harus disertai rekomendasi Gubernur yang sudah mendapatkan pertimbangan

Tabel 4. Gap kebijakan dalam penyediaan/pencadangan lahan hutan tanaman.

Table 4. Policy gaps in provision/reserve for forest plantation land.

\begin{tabular}{|c|c|c|c|c|}
\hline No & $\begin{array}{l}\text { Keberadaan kebijakan lain } \\
\text { di tingkat daerah } \\
\text { (The existence of other policies } \\
\text { in the local level) }\end{array}$ & $\begin{array}{l}\text { Jumlah responden } \\
\text { (Total respondent) }\end{array}$ & $\begin{array}{l}\text { \% jumlah responden } \\
\text { (Percentage of total } \\
\text { respondent) }\end{array}$ & $\begin{array}{l}\text { Keterangan } \\
\text { (Remarks) }\end{array}$ \\
\hline 1 & Ada & - & - & - \\
\hline 2 & Tidak ada & 18 & 100 & $\begin{array}{c}\text { (HTI, HKm, dan } \\
\text { HTR) }\end{array}$ \\
\hline & Jumlah (Total) & 18 & 100 & \\
\hline
\end{tabular}

Sumber (Source): Permenhut No. P.19/2007 Jo P.11/2008.

Tabel 5. Biaya pengurusan ijin IUPHHK (biaya transaksi).

Table 5. IUPHHK clearance permit fee (transaction costs).

\begin{tabular}{cccccccc}
\hline & Besarnya biaya & \multicolumn{6}{c}{ Responden di tingkat (Respondent at level) } \\
\cline { 3 - 8 } No & $\begin{array}{c}\text { pengurusan } \\
\text { Arrangement cost) }\end{array}$ & \multicolumn{2}{c}{ Pusat (Central) } & Provinsi (Province) & Kabupaten/Kota (District) \\
\cline { 3 - 8 } & $($ Rp) & Jumlah (Total) & $\%$ & Jumlah (Total) & $\%$ & Jumlah (Total) & $\%$ \\
\hline 1 & $20-30$ juta & - & - & 1 & 5,56 & - & - \\
2 & $31-50$ juta & - & - & 3 & 16,67 & - & - \\
3 & $51-100$ juta & 9 & 50,00 & 4 & 22,22 & 13 & 72,22 \\
4 & $101-150$ juta & 1 & 5,56 & 6 & 33,33 & 2 & 11,11 \\
5 & $151-200$ juta & 4 & 22,22 & 3 & 16,67 & 3 & 16,67 \\
6 & $201-299$ juta & 1 & 5,56 & 1 & 5,56 & - & - \\
7 & Lainnya & 3 & 16,67 & - & - & - & - \\
\hline & Jumlah (Total) & 18 & 100 & 18 & 100 & 18 & 100 \\
\hline
\end{tabular}


secara teknis maupun administrasi dari Bupati/Walikota, dan terhadap lahan tersebut sudah dilakukan verifikasi lahan. Secara tidak langsung tim gabungan telah dibentuk oleh pemda setempat untuk melakukan verifikasi lapangan dengan tujuan apakah lahan yang dimohon sudah clean and clear dan untuk melakukan hal tersebut pemerintah tidak menyediakan anggaran atau dana, secara tidak langsung pembiayaan tersebut dibebankan kepada pemohon ijin IUPHHK.

\section{Aturan Main}

Keberhasilan pembangunan hutan tanaman tercermin dalam aturan main. Aturan main yang dimaksud adalah pedoman yang harus dilakukan dalam keseluruhan proses perijinan IUPHHK pada hutan tanaman. Aturan main ini terdiri dari kriteria dan persyaratan yang harus dipenuhi, mekanisme penilaian yang digunakan, termasuk pihak yang dapat melakukan penilaian dan cara penilaian yang memenuhi kriteria transparan, partisipatif dan akuntabel. Mekanisme permohonan kepada Menteri Kehutanan juga merupakan bagian dari aturan main karena dalam proses perijinannya sangat terkait antara satu tahapan dengan tahapan lainnya. Keseluruhan aturan main telah di atur dalam Permenhut No. P.19/2007 Jo P.11/2008 (untuk HTI).

\section{Kriteria dan Persyaratan}

\section{a. Status dan Kriteria Permohonan Ijin}

Permohonan ijin IUPHHK dapat diikuti oleh siapa saja yang berminat dan kompeten dalam pengelolaan dan pemanfatan hutan. Terbukanya kesempatan bagi semua pihak juga untuk menghindari terciptanya konglomerasi dan penumpukan sumber daya yang mengarah pada ketidakadilan ekonomi. Status peserta yang dapat mengikuti proses perijinan berdasarkan Permenhut No. P.19/2007 Jo
P.11/2008, di antaranya adalah: perorangan, koperasi, badan usaha milik swasta (PT, CV, Firma) dan badan usaha milik negara atau badan usaha milik daerah.

Untuk melakukan proses perijinan setiap pemohon harus mempunyai komitmen terhadap pemanfaatan hutan lestari dalam jangka panjang dan mengikuti setiap tahapan dalam proses perijinan yang bebas KKN. Pemohon yang dapat mengikuti proses perijinan IUPHHK melalui mekanisme permohonan kepada Menteri Kehutanan juga harus memiliki beberapa kriteria lain, yaitu (Anonim, 2004):

1) Tidak pernah menjadi perusahaan yang pernah menunggak Dana Reboisasi (DR) dan Provisi Sumber Daya Hutan (PSDH).

2) Bukan merupakan perusahaan yang dikategorikan sebagai perusak lingkungan seperti yang disebutkan dalam pasal 50 UU No. 41 tahun 1999.

3) Tidak memiliki afiliasi perusahaan yang pernah memiliki track record melakukan praktik kejahatan hutan.

4) Tidak pernah dimasukkan dalam daftar Badan Penyehatan Perbankan Nasional (BPPN) sebagai debitur yang tidak kooperatif.

Keempat kriteria tersebut harus dipe-nuhi dengan membuat surat pernyataan tertulis dari para pemohon. Hal tersebut ditempuh untuk menjaga apabila di kemudian hari terbukti bahwa pernyataan di atas tidak benar, Kementerian Kehutanan dapat mengambil langkah seperti: a) Mencabut IUPHHK yang telah diberikan seandainya perusahaan tersebut menjadi pemegang IUPHHK atau b) Dapat mendiskualifikasi pemohon tersebut pada awal dalam proses perijinan IUPHHK.

\section{Persyaratan Teknis}

Secara keseluruhan persyaratan proposal teknis untuk HTI diatur dalam Permenhut No. P.19/2007 Jo P.11/2008 yang mem- 
presentasikan persyaratan dari berbagai aspek secara memadai.

\section{Rekomendasi Gubernur}

Dalam PP 6/2007 dan Permenhut No. P.19/2007 Jo P.11/2008 telah diatur bahwa setiap pemohon ijin IUPHHK wajib melampirkan rekomendasi Gubernur ketika mengajukan permohonan ijin IUPHHK kepada Menteri Kehutanan. Rekomendasi Gubernur diberikan setelah mendapatkan pertimbangan dari Bupati/Walikota yang didasarkan pada pertimbangan teknis dari Kepala Dinas Kehutanan Kabupaten/Kota. Permenhut tersebut juga mewajibkan setiap rekomendasi yang diberikan oleh Gubernur harus sudah dilakukan telaahan teknis dari Dinas Kehutanan Provinsi dan telaahan kawasan hutan yang dilakukan oleh BPKH setempat. Hal ini merupakan perwujudan pembagian kewenangan antara pusat dan daerah dalam kerangka otonomi daerah.

Ketentuan tersebut harus dipertahan-kan dengan tetap mengacu pada prinsip-prinsip good governance berdasarkan UU No. 28 tahun 1999 tentang Penyelenggaraan Negara yang Bersih dan Bebas dari Korupsi, Kolusi dan Nepotisme (KKN). Pedoman pemberian rekomendasi dari Bupati/Walikota dan Gubernur harus ditetapkan secara jelas untuk dijadikan sebagai acuan dan diberlakukan di seluruh Indonesia, baik terhadap calon areal IUPHHK maupun calon pemegang IUPHHK di wilayahnya. Akan tetapi dengan diterbitkannya Permenhut No. P.63/2008 tentang Tata Cara Pemberian Rekomendasi Gubernur dalam rangka Permohonan atau Perpanjangan Ijin Usaha Pemanfaatan Hasil Hutan Kayu (IUPHHK) Hutan Alam atau Hutan Tanaman, bunyi pasal dalam PP 6/2007 dan P.11/ 2008 yang mewajibkan setiap permohonan ijin IUPHHK harus disertai rekomendasi dari Gubernur menjadi tidak tegas dan jelas. $\mathrm{Hal}$ tersebut dapat dilihat pada pasal 4 ayat (5)
Permenhut No. P.63/2008 yang menyatakan bahwa "Dalam hal telah dilakukan konfirmasi sebagai-mana dimaksud pada ayat (2), (3) dan (4) dan rekomendasi sebagaimana dimaksud pada ayat (1) tidak diterbitkan, Menteri Kehutanan memproses penerbitan IUPHHK-HT atau IUPHHK-HA sesuai kewenangan yang di atur pasal 4 ayat (2) UU No. 41 tahun 1999”. Bunyi pasal tersebut menunjukkan bahwa perijinan IUPHHK akan terus diproses walaupun tidak dilampiri Rekomendasi Gubernur. Bunyi pasal tersebut tidak sinkron dengan aturan yang telah diterbitkan (PP 6/2007 dan P.11/2008) karena apabila kita lihat filosofi dari bunyi aturan yang mewajibkan setiap pemohon IUPHHK melampirkan Rekomendasi Gubernur setempat, ini merupakan salah satu perwujudan adanya koordinasi antara pemerintah pusat, pemerintah provinsi dan kabupaten/kota, hal tersebut telah sesuai dengan UU No. 32/2004 tentang Pemerintahan Daerah dan PP 38/2007 tentang Pembagian Urusan Pemerintahan antara Pemerintah, Pemerintah Daerah Provinsi, dan Pemerintahan Daerah Kabupaten/Kota.

\section{KESIMPULAN DAN SARAN}

\section{A. Kesimpulan}

Secara keseluruhan persyaratan proposal teknis untuk HTI yang diatur dalam Permenhut No. P.19/2007 Jo P.11/2008 telah mempresentasikan persyaratan dari berbagai aspek secara baik. Dinas Kehutanan Kabupaten memberikan pertimbangan teknis berkaitan dengan layak-tidaknya pemohon IUPHHK dan layak-tidaknya areal yang akan dijadikan lahan untuk pembangunan hutan tanaman dengan melihat kondisi kawasan hutan yang ada. Di lain pihak pertimbangan teknis yang dilakukan oleh Dinas Kehutanan Provinsi lebih kepada apakah areal yang dimohon telah sesuai dengan peruntukan pembangunan pada tataran provinsi. Dengan 
diterbitkannya Permenhut No. P.63/2008 tentang Tata Cara Pemberian Rekomendasi Gubernur dalam rangka Permohonan atau Perpanjangan Ijin Usaha Pemanfaatan Hasil Hutan Kayu (IUPHHK) Hutan Tanaman, berdampak kepada bunyi pasal dalam PP 6/2007 dan P.11/2008 yang mewajibkan setiap permohonan ijin IUPHHK harus disertai Rekomendasi Gubernur menjadi tidak tegas dan jelas. Dalam proses pengurusan ijin IUPHHK pada hutan tanaman memerlukan waktu minimal satu tahun, hal tersebut menunjukkan bahwa proses perijinan IUPHHK tersebut belum efektif.

\section{B. Saran}

Diperlukan perlakuan khusus berkaitan dengan pengurusan ijin IUPHHK, yaitu dengan membuat "pengurusan ijin satu pintu" (onestop service). Proses pelaksanaaan perijinan IUPHHK melibatkan banyak institusi sehingga memerlukan waktu yang lama dan biaya yang tinggi. Pedoman pem-berian rekomendasi dari Bupati/Walikota dan Gubernur harus ditetapkan secara jelas sebagai dasar acuan di seluruh Indonesia dalam memberikan rekomendasi, baik terhadap calon areal IUPHHK maupun calon pemegang IUPHHK di wilayahnya.

Agar dilakukan sosialisasi secepatnya mengenai aturan atau kebijakan yang baru berkaitan dengan mekanisme proses perijinan IUPHHK karena proses perijinan memerlukan waktu cukup lama dan biaya yang tinggi serta melibatkan institusi di luar kehutanan (stakeholder). Diperlukan uji coba terhadap materi kebijakan yang akan dikeluarkan Kementerian Kehutanan sehingga bila Keputusan Menteri Kehutanan atau Peraturan Menteri Kehutanan tersebut diterbitkan/ dikeluarkan sudah dapat dilaksanakan dengan baik.

\section{DAFTAR PUSTAKA}

Anonim. (2004). Evolusi mekanisme perijinan usaba pemanfaatan hasil butan kayu pada butan alam dan butan tanaman. (Kertas Kerja Nomor 06). Jakarta: Indonesia Coruption Watch (ICW).

Keputusan Menteri Kehutanan No. 177/ 2003 tentang Kriteria dan Indikator Pengelolaan Hutan secara Lestari pada Unit Manajemen Usaha Pemanfaatan Hutan Tanaman.

Direktorat Jenderal Bina Produksi Kehutanan. (2009). Data release 2009 triwulan II. Jakarta: Direktorat Jenderal Bina Produksi Kehutanan.

Peraturan Pemerintah No. 6 Tahun 2007 tentang Tata Hutan dan Penyusunan Rencana Pengelolaan Hutan serta Pemanfaatan Hutan.

Peraturan Pemerintah No. P.3/MenhutII/2008 Tahun 2008 tentang Perubahan Tata Hutan dan Penyusunan Rencana Pengelolaan Hutan serta Pemanfaatan Hutan.

Peraturan Menteri Kehutanan No. P.19/ Menhut-II/2007 Tahun 2007 tentang Tata Cara Pemberian Ijin dan Perluasan Areal Kerja Usaha Pemanfaatan Hasil Hutan Kayu pada Hutan Tanaman Industri dalam Hutan Tanaman pada Hutan Produksi.

Peraturan Menteri Kehutanan No. P.60/ Menhut-II/2007 Tahun 2007 tentang Perubahan Peraturan Menteri Kehutanan No. P.19/Menhut-II/2007 Tahun 2007 tentang Tata Cara Pemberian Izin dan Perluasan Areal Kerja Usaha Pemanfaatan Hasil Hutan Kayu pada Hutan Tanaman Industri dalam Hutan Tanaman pada Hutan Produksi. 
Peraturan Menteri Kehutanan No. P.11/ Menhut-II/2008 Tahun 2008 tahun 2008 tentang Perubahan Kedua Peraturan Menteri Kehutanan No. P.19/Menhut-II/ 2007 Tahun 2007 tentang Tata Cara Pemberian Ijin dan Perluasan Areal Kerja Usaha Pemanfaatan Ha-sil Hutan Kayu pada Hutan Tanaman Industri dalam Hutan Tanaman pada Hutan Produksi.

Peraturan Pemerintah No. 38 Tahun 2007 tentang Pembagian Urusan Pemerintahan antara Pemerintah, Pemerintah Daerah Provinsi, dan Pemerintahan Daerah Kabupaten/Kota.

Sugiyono. (2004). Metode penelitian bisnis. (Cetakan ketujuh). Bandung: Alfa-beta.

Undang-Undang No. 41 Tahun 1999 tentang Kehutanan.

Undang-Undang No. 32 Tahun 2004 tentang Pemerintahan Daerah.

Undang Undang No. 28 Tahun 1999 tentang Penyelenggaraan Negara yang Bersih dan Bebas dari Korupsi, Kolusi dan Nepotisme (KKN).
Peraturan Menteri Kehutanan No.P.37/ Menhut-II/2007 Tahun 2007 tentang Hutan Kemasyarakatan.

Peraturan Menteri Kehutanan No.P.18/ Menhut-II/2009 Tahun 2009 tentang perubahan atas peraturan tentang Hutan Kemasyarakatan.

Peraturan Menteri Kehutanan No.P.23/ Menhut-II/2007 Tahun 2007 tentang Tata Cara Permohonan Izin Usaha Pemanfaatan Hasil Hutan Kayu Dalam Hutan Tanaman Rakyat Dalam Hutan Tanaman.

Peraturan Menteri Kehutanan No. P.48/ Menhut-II/2008 tentang Standar Biaya Pembangunan Hutan Tanaman Industri.

Peraturan Menteri Kehutanan No. P.63/ Menhut-II/2008 Tahun 2008 tentang Tata Cara Pemberian Rekomendasi Gubernur dalam rangka Permohonan atau Perpanjangan Ijin Usaha Pemanfaatan Hasil Hutan Kayu (IUPHHK) Hutan Tanaman. 
Lampiran 1. Biaya pengurusan IUPHHK (biaya transaksi). Appendix 1. Arrangements costs IUPHHK (transaction cost).

\begin{tabular}{|c|c|c|c|c|c|c|c|c|c|c|c|c|c|c|c|c|c|c|c|c|c|c|}
\hline \multirow{3}{*}{ No } & \multirow{3}{*}{$\begin{array}{l}\text { Responden } \\
\text { (Respondent) }\end{array}$} & \multicolumn{21}{|c|}{ Biaya pengurusan/transaksi (Arrangements cost/transaction cost) } \\
\hline & & \multicolumn{7}{|c|}{ Tingkat Pusat (Central) } & \multicolumn{7}{|c|}{ Tingkat Provinsi (Province) } & \multicolumn{7}{|c|}{$\begin{array}{c}\text { Tingkat Kabupaten/Kota } \\
\text { (District) }\end{array}$} \\
\hline & & 1 & 2 & 3 & 4 & 5 & 6 & 7 & 1 & 2 & 3 & 4 & 5 & 6 & 7 & 1 & 2 & 3 & 4 & 5 & 6 & 7 \\
\hline 1 & 1 & - & - & - & $\sqrt{ }$ & - & - & - & & - & - & $\sqrt{ }$ & - & - & - & - & - & $\sqrt{ }$ & - & - & - & - \\
\hline 2 & 2 & - & - & $\sqrt{ }$ & - & - & - & - & - & $\sqrt{ }$ & - & - & - & - & - & - & - & $\sqrt{ }$ & - & - & - & - \\
\hline 3 & 3 & - & - & - & - & $\sqrt{ }$ & - & - & - & - & - & $\sqrt{ }$ & - & - & - & - & - & $\sqrt{ }$ & - & - & - & - \\
\hline 4 & 4 & - & - & $\sqrt{ }$ & - & - & - & - & - & $\sqrt{ }$ & - & - & - & - & - & - & - & $\sqrt{ }$ & - & - & - & - \\
\hline 5 & 5 & - & - & $\sqrt{ }$ & - & - & - & - & 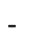 & $\sqrt{ }$ & - & - & - & - & - & - & - & $\sqrt{ }$ & - & - & - & - \\
\hline 6 & 6 & - & - & - & - & $\sqrt{ }$ & - & - & - & - & - & $v$ & - & - & - & - & - & $\sqrt{ }$ & - & - & - & - \\
\hline 7 & 7 & - & - & $\sqrt{ }$ & - & - & - & - & - & - & $\sqrt{ }$ & - & - & - & - & - & - & $\sqrt{ }$ & - & - & - & - \\
\hline 8 & 8 & - & - & - & - & $\sqrt{ }$ & - & - & - & - & - & - & $\sqrt{ }$ & - & - & - & - & - & - & $\sqrt{ }$ & - & - \\
\hline 9 & 9 & - & - & - & - & - & - & $\sqrt{ }$ & - & - & - & - & $\sqrt{ }$ & - & - & - & - & $\sqrt{ }$ & - & - & - & - \\
\hline 10 & 10 & - & - & - & - & - & - & $\sqrt{ }$ & - & - & - & $\sqrt{ }$ & - & - & - & - & - & $\sqrt{ }$ & - & - & - & - \\
\hline 11 & 11 & - & - & $\sqrt{ }$ & - & - & - & - & - & - & $\sqrt{ }$ & - & - & - & - & - & - & $\sqrt{ }$ & - & - & - & - \\
\hline 12 & 12 & - & - & - & - & - & - & $\sqrt{ }$ & - & - & - & $v$ & - & - & - & - & - & - & $\sqrt{ }$ & - & - & - \\
\hline 13 & 13 & - & - & - & - & - & $\sqrt{ }$ & - & - & - & - & $V$ & - & - & - & - & - & $\sqrt{ }$ & - & - & - & - \\
\hline 14 & 14 & - & - & $\sqrt{ }$ & - & - & - & - & - & - & $\sqrt{ }$ & - & - & - & - & - & - & $\sqrt{ }$ & - & - & - & - \\
\hline 15 & 15 & - & - & - & - & $\sqrt{ }$ & - & - & - & - & - & - & $\sqrt{ }$ & - & - & - & - & - & - & $\sqrt{ }$ & - & - \\
\hline 16 & 16 & - & - & $\sqrt{ }$ & - & - & - & - & - & - & $\sqrt{ }$ & - & - & - & - & - & - & $\sqrt{ }$ & - & - & - & - \\
\hline 17 & 17 & - & - & $\sqrt{ }$ & - & - & - & - & $v$ & - & - & - & - & - & - & - & - & - & $\sqrt{ }$ & - & - & - \\
\hline 18 & 18 & - & - & $\sqrt{ }$ & - & - & - & - & - & - & - & - & - & $\sqrt{ }$ & - & - & - & - & - & $\sqrt{ }$ & - & - \\
\hline \multicolumn{2}{|c|}{ Jumlah (Total) } & - & - & 9 & 1 & 4 & 1 & 3 & 1 & 3 & 4 & 6 & 3 & 1 & - & - & - & 13 & 2 & 3 & - & - \\
\hline
\end{tabular}

Keterangan (Remarks): Untuk masing-masing tingkat pemerintahan (pusat, provinsi, kabupaten/kota): $120 \mathrm{~s} / \mathrm{d} 30$ juta

$231 \mathrm{~s} / \mathrm{d} 50$ juta

$351 \mathrm{~s} / \mathrm{d} 100$ juta

$4101 \mathrm{~s} / \mathrm{d} 150$ juta

$5151 \mathrm{~s} / \mathrm{d} 200$ juta

$6201 \mathrm{~s} / \mathrm{d} 250$ juta

$7>250$ juta 
Lampiran 2. Lama proses pengurusan IUPHHK. Appendix 2. Duration of arrangement process IUPHHK.

\begin{tabular}{|c|c|c|c|c|c|}
\hline \multirow{2}{*}{ No } & \multirow{2}{*}{$\begin{array}{l}\text { Responden } \\
\text { (Respondent) }\end{array}$} & \multicolumn{4}{|c|}{ Lama pengurusan ijin IUPHHK (Duration of arrangement IUPHHK permit) } \\
\hline & & $0-1$ tahun (year) & 1-2 tahun (year) & $>2$ tahun (year) & Lainnya (others) \\
\hline 1 & 1 & $\sqrt{ }$ & - & - & - \\
\hline 2 & 2 & $\sqrt{ }$ & - & - & - \\
\hline 3 & 3 & $\sqrt{ }$ & - & - & - \\
\hline 4 & 4 & $\sqrt{ }$ & - & - & - \\
\hline 5 & 5 & $\sqrt{ }$ & - & - & - \\
\hline 6 & 6 & - & $\sqrt{ }$ & - & - \\
\hline 7 & 7 & $\sqrt{ }$ & - & - & - \\
\hline 8 & 8 & $\sqrt{ }$ & - & - & - \\
\hline 9 & 9 & - & - & $\sqrt{ }$ & - \\
\hline 10 & 10 & $\sqrt{ }$ & - & - & - \\
\hline 11 & 11 & $\sqrt{ }$ & - & - & - \\
\hline 12 & 12 & $\sqrt{ }$ & - & - & - \\
\hline 13 & 13 & - & $\sqrt{ }$ & - & - \\
\hline 14 & 14 & - & $\sqrt{ }$ & - & - \\
\hline 15 & 15 & $\sqrt{ }$ & - & - & - \\
\hline 16 & 16 & - & $\sqrt{ }$ & - & - \\
\hline 17 & 17 & $\sqrt{ }$ & - & - & - \\
\hline 18 & 18 & $\sqrt{ }$ & - & - & - \\
\hline \multicolumn{2}{|c|}{ Jumlah (Total) } & 13 & 4 & 1 & 0 \\
\hline
\end{tabular}

Lampiran 3. Informasi keberadaan standar operasional (SOP). Appendix 3. Information of procedure operation standard.

\begin{tabular}{ccccc}
\hline \multirow{2}{*}{ No } & Responden $($ Respondent $)$ & \multicolumn{2}{c}{ Keberadaan SOP (The existence of SOP) } & \multirow{2}{*}{ Keterangan (Remarks) } \\
\cline { 3 - 4 } & 1 & Ada $($ yes $)$ & Tidak ada $($ No $)$ & \\
\hline 1 & 2 & $\sqrt{ }$ & - \\
3 & 3 & $\sqrt{ }$ & - \\
4 & 4 & $\sqrt{ }$ & - \\
5 & 5 & $\sqrt{ }$ & - \\
6 & 6 & $\sqrt{ }$ & - \\
7 & 7 & $\sqrt{ }$ & - \\
8 & 8 & $\sqrt{ }$ & - \\
9 & 9 & $\sqrt{ }$ & - \\
10 & 10 & $\sqrt{ }$ & - \\
11 & 11 & $\sqrt{ }$ & - \\
12 & 12 & $\sqrt{ }$ & - \\
13 & 13 & $\sqrt{ }$ & - \\
14 & 14 & $\sqrt{ }$ & - \\
15 & 15 & $\sqrt{ }$ & - \\
16 & 16 & $\sqrt{ }$ & - \\
17 & 17 & 18 & 0 \\
18 & 18 & Jumlah (Total) &
\end{tabular}

Keterangan (Remarks): SOP yang digunakan dalam proses penyediaan/pencadangan lahan hutan tanaman adalah Permenhut No. P.19/2007 Jo P.11/2008. 
Lampiran 4. Proses pengurusan ijin satu pintu. Appendix 4. One stop service process.

\begin{tabular}{|c|c|c|c|c|c|c|c|}
\hline \multirow{3}{*}{ No } & \multirow{3}{*}{$\begin{array}{l}\text { Responden } \\
\text { (Respondent) }\end{array}$} & \multicolumn{6}{|c|}{ Proses perïinan satu pintu (One stop service process)* } \\
\hline & & \multicolumn{2}{|c|}{ Pusat (Central) } & \multicolumn{2}{|c|}{ Provinsi (Province) } & \multicolumn{2}{|c|}{ Kabupaten/Kota (District) } \\
\hline & & $\begin{array}{l}\text { Setuju } \\
\text { (Agree) }\end{array}$ & $\begin{array}{c}\text { Tidak } \\
\text { (Not agree) }\end{array}$ & $\begin{array}{l}\text { Setuju } \\
\text { (Agree) }\end{array}$ & $\begin{array}{c}\text { Tidak } \\
\text { (Not agree) }\end{array}$ & $\begin{array}{c}\text { Setuju } \\
\text { (Agree) }\end{array}$ & $\begin{array}{c}\text { Tidak } \\
\text { (Not agree) }\end{array}$ \\
\hline 1 & 1 & $\sqrt{ }$ & - & $\sqrt{ }$ & - & $\sqrt{ }$ & - \\
\hline 2 & 2 & $\sqrt{ }$ & - & $\sqrt{ }$ & - & $\sqrt{ }$ & - \\
\hline 3 & 3 & $\sqrt{ }$ & - & $\sqrt{ }$ & - & $\sqrt{ }$ & - \\
\hline 4 & 4 & $\sqrt{ }$ & - & $\sqrt{ }$ & - & $\sqrt{ }$ & - \\
\hline 5 & 5 & $\sqrt{ }$ & - & $\sqrt{ }$ & - & $\sqrt{ }$ & - \\
\hline 6 & 6 & $\sqrt{ }$ & - & $\sqrt{ }$ & - & $\sqrt{ }$ & - \\
\hline 7 & 7 & $\sqrt{ }$ & - & $\sqrt{ }$ & - & $\sqrt{ }$ & - \\
\hline 8 & 8 & $\sqrt{ }$ & - & - & $\sqrt{ }$ & - & $\sqrt{ }$ \\
\hline 9 & 9 & $\sqrt{ }$ & - & $\sqrt{ }$ & - & $\sqrt{ }$ & - \\
\hline 10 & 10 & $\sqrt{ }$ & - & $\sqrt{ }$ & - & $\sqrt{ }$ & - \\
\hline 11 & 11 & $\sqrt{ }$ & - & $\sqrt{ }$ & - & $\sqrt{ }$ & - \\
\hline 12 & 12 & - & $\sqrt{ }$ & $\sqrt{ }$ & - & - & $\sqrt{ }$ \\
\hline 13 & 13 & $\sqrt{ }$ & - & $\sqrt{ }$ & - & $\sqrt{ }$ & - \\
\hline 14 & 14 & $\sqrt{ }$ & - & $\sqrt{ }$ & - & $\sqrt{ }$ & - \\
\hline 15 & 15 & $\sqrt{ }$ & - & - & $\sqrt{ }$ & - & $\sqrt{ }$ \\
\hline 16 & 16 & $\sqrt{ }$ & - & $\sqrt{ }$ & - & $\sqrt{ }$ & - \\
\hline 17 & 17 & - & $\sqrt{ }$ & - & $\sqrt{ }$ & - & $\sqrt{ }$ \\
\hline 18 & 18 & - & $\sqrt{ }$ & - & $\sqrt{ }$ & - & $\sqrt{ }$ \\
\hline \multicolumn{2}{|c|}{ Jumlah (Total) } & 15 & 3 & 14 & 4 & 13 & 5 \\
\hline
\end{tabular}

Keterangan (Remarks): *Untuk masing-masing tingkat pemerintahan (pusat, provinsi, kabupaten/kota). 